\title{
Vicepræsidentposten i amerikansk politik
}

\section{Mads Fuglede}

Med John McCains valg af Sarah Palin er vicepræsidentposten kommet på alles læber. Men hvor vigtig er den post egentlig? Havde Benjamin Franklin ret, da han giftigt foreslog, at man skulle tiltale vicepræsidenten med: 'Deres overflødighed?' Her følger et historisk tilbageblik

Tidligt i 2000, mens George W. Bush kæmpede indædt mod John McCain om sit partis nomination, fløj Joe Allbaugh til Dallas for at mødes med Richard Cheney.

Joe Allbaugh var kampagneleder for Bush og var i gang med at forberede en liste over mulige vicepræsidentkandidater. Ifølge journalisten Robert Draper spurgte Allbaugh, om Cheney kunne tænke sig at være Bushs vicepræsident, men fik det svar, at det ville være en dårlig idé af to grunde: Begge havde en baggrund i olieindustrien (Cheney var på det tidspunkt administrerende direktør for Halliburton, og Bush havde stiftet olieselskabet Arbusto Energy tilbage i 1977), hvilket ville få deres kandidatur til at fremstå en- sidigt. Desuden forbød den amerikanske forfatning med sin 12. tilføjelse, at to kandidater, der var borgere i samme stat, stillede op sammen.

Joe Allbaugh fløj tilbage til Austin, Texas, med uforrettet sag. Det interessante ved samtalen er, at Cheneys argumenter var så dårlige, at de ikke kan have været den egentlige bevæggrund bag afvisningen. Det er mere sandsynligt, at Cheney vidste, at det embede, han blev tilbudt, ikke var særligt eftertragtet.

Richard Cheney havde været tæt på magten før, som stabschef (197577) for præsident Gerald Ford og forsvarsminister (1989-93) for præsident George H. W. Bush, og vidste, at vicepræsidentembedet var usæd- 
vanligt vanskeligt at bestride og hovedsagligt var underlagt præsidentens luner.

I offentligheden opfattede man embedet som et, der blot bestod i, at man skulle være parat til at træde til, hvis præsidenten skulle dø.

Blandt historikere og politologer var der en udbredt opfattelse af, at vicepræsidentembedet var tæt på at være indholdsløst og ikke rummede meget andet end en mulighed for selv på sigt at blive præsident (siden embedets undfangelse er 1 ud af 4 vicepræsidenter senere blevet præsident enten ved valg, dødsfald eller fordi, præsidenten selv har trukket sig).

Cheney havde tidligere ønsket at stille op som præsident, men havde indset, at han simpelthen ikke havde appel nok hertil - og i 2000 havde han heller ikke helbredet til embedet.

Det er således sandsynligt, at Cheney måtte sende Allbaugh hjem til Austin, Texas, med et nej, fordi han var enig med USA's første vicepræsident, John Adams (1789-97), i at posten var det mest ubetydelige embede nogensinde udtænkt af menneskeheden. Benjamin Franklin foreslog, at man skulle tiltale vicepræsidenten med: 'Deres overflødighed' (Your Superfluous Excellency).

En tiltale, der senere aldrig skulle blive rettet mod Richard Cheney som vicepræsident.

Senere samme forår ringede George W. Bush selv til Cheney og spurgte, om han ikke ville være behjælpelig med at finde en vicepræsidentkandidat for ham. Historien har vist, at vicepræsidenter oftere skader præsidentkandidaten end de hjælper ham under valgkampen.

\section{Vicepræsidenten og valgkampen}

Den eneste vicepræsident i USA's historie, som med sikkerhed har haft en afgørende indflydelse på valgresultatet, er Lyndon B. Johnson, der havde så gode kontakter i texansk politik og var så populær sammesteds, at staten med et lille flertal stemte demokratisk ved præsidentvalget i 1960 .

Derimod fik Walter Mondale ethvert håb om at få Det Hvide Hus vristet fra Ronald Reagan ødelagt i 1984 af sit valg af vicepræsidentkandidat. Mondale havde satset på at bringe ny energi og fokus tilbage $\mathrm{i}$ valgkampen ved at stille op sammen med USA's første kvindelige vicepræsidentkandidat, Geraldine Ferraro.

Det virkede, lige indtil en skattesag om Ferraros mand stjal al opmærksomheden og fik vælgerne til at tvivle på Mondales dømmekraft. Situationen var lignende i 1972, da det blev afsløret, at Thomas Eagleton flere gange havde været indlagt med psykiske problemer og var blevet behandlet med chokbehandling to gange. George McGovern, der var demokraternes præsidentkandidat, havde valgt Eagleton som sin mulige 
vicepræsident og kom nu i strid modvind for sin evne til at træffe vigtige beslutninger.

I en tid, hvor amerikanerne inden for en kort årrække havde måttet begrave John og Robert F. Kennedy samt Martin Luther King som ofre for politisk motiverede mord, var det bestemt ikke uvæsentligt, hvem der var landets vicepræsident - han kunne meget vel ende som præsident, og få ønskede, at den person, der havde adgang til verdens mest moderne a-våben-arsenal i perioder, kunne være psykisk uligevægtig.

Der havde været rygter om Thomas Eagletons indlæggelser, da han blev valgt til senatet for Missouri, men de havde aldrig nået offentligheden, da pressen havde vurderet, at der er en væsentlig forskel på at være senator og vicepræsident. McGovern endte med at droppe Eagleton, men skaden var sket.

I 1992 var der heller ikke mange, der mente, at Dan Quayle var et aktiv for George H. W. Bushs mislykkedes forsøg på at blive genvalgt. Derfor foregår der en proces, amerikanerne kalder for vetting, hvor alle mulige kandidater gennemgås meget kritisk for især at undersøge, om der falder et skelet ud af skabet, der kan skade præsidentkandidaten.

Når man har en liste af vettede kandidater, begynder man at veje deres forskellige styrker og svagheder for at se, hvad de kan bidrage med. Det var denne proces, George W. Bush bad Cheney om at forestå.

\section{Udvælgelseskriterier}

Der kan være mange grunde til at vælge en specifik vicepræsidentkandidat. De mest almindelige overvejelser ser ud som følgende:

Geografiske hensyn: Vicepræsidentkandidaten skal supplere præsidentkandidaten ved at være fra en anden region af USA. Især hvis præsidentkandidaten er fra New England, så vil vicepræsidentkandidaten med stor sandsynlighed være fra Midtvesten eller Syden.

En anden vigtig faktor er, at vicepræsidentkandidaten meget gerne må være fra en af de såkaldte swing states, hvor valget reelt afgøres. $\mathrm{Og}$ meget gerne fra swing states som Florida, Pennsylvania eller Ohio. Lyndon B. Johnson, Hubert H. Humphrey, Dan Quayle, Lloyd Bentsen og John Edwards er alle eksempler på vicepræsidentkandidater, der hører under denne kategori.

Ideologisk balance: Ofte medfører primærvalgene, at fløjene hos demokraterne og republikanerne kriges så voldsomt, at det er nødvendigt at pege på en vicepræsidentkandidat, der kan udligne præsidentkandidatens position for at sørge for, at partiet ikke falder fra hinanden. Valget af vicepræsidentkandidaterne Lyndon B. Johnson, Hubert H. Humphrey, Spiro T. Agnew, George H. W. Bush og Dan Quayle er eksempler herpå. 
Til støtte for arbejdet med Kongressen: På en lang række områder er den udøvende magt i USA usædvanlig svag i forhold til den lovgivende. Noget af det værste, der kan ske for en præsident, er at blive det, amerikanerne kalder en lame duck, som betyder, at præsidenten er lammet af Kongressen, og at USA mere eller mindre bliver ledet hen over hovedet på præsidenten af lederskabet i Kongressen.

Det skete i lange perioder for præsident Bill Clinton og er en position, der kan undgås ved at vælge en med et stort netværk i Washington som vicepræsidentkandidat. Lyndon B. Johnson, William E. Miller, Walter Mondale, Joe Biden og Richard Cheney er alle eksempler på denne type vicepræsident.

\section{For at veje op mod presidentkandidaten} aldersmassigt: Hvis præsidentkandidaten er meget ung eller gammel, kan det være en overvejelse at pege på en vicepræsidentkandidat, der afbalancerer dette. Det har helt sikkert spillet en rolle for John McCains valg af Alaskas kvindelige guvernør Sarah Palin son sin vicepræsidentkandidat, akkurat som det også spillede en rolle ved valget af $\mathrm{Ri}-$ chard Cheney, Joe Biden og Dan Quayle.

Ideologisk fellesskab: En udvikling, man har set af især det nyere præsidentembede, er at præsidenten ønsker en vicepræsident, med hvem han eller hun deler ideologisk ståsted. I visse tilfælde er der snarere tale om en art parløb, selvom dette hurtigt afslører sig som en fiktion, da deres magtbeføjelser er så forskellige. Walther F. Mondale, Geraldine Ferraro, Al Gore, John Edwards og Richard Cheney delte alle udpræget ideologisk ståsted med præsidentkandidaten.

Der er en lang række andre motiver, der gør sig gældende. Barry Goldwater forklarede sit valg af William E. Miller med, at han vidste, at denne drev modkandidaten Lyndon B. Johnson til vanvid. Nixons valg af Spiro T. Agnew syntes til dels at være styret af et motiv om at have en medkandidat, som ikke ville stjæle rampelyset fra ham.

Richard Cheney indvilligede $i$ at hjælpe Bush, der gav ham en meget simpel karakteristik af den vicepræsidentkandidat, han ledte efter. En lettere omskrivning af Bushs krav lød: "Jeg ved ikke, hvad der ender på min dagsorden i Det Hvide Hus, så jeg har brug for en ved min side, der har set det hele før". Dernæst $\emptyset n s k e d e$ Bush ikke en vicepræsident, der havde politiske ambitioner, som kunne give sig udslag i illoyal opførsel. Richard Cheney vendte snart tilbage og accepterede, at han var den bedst egnede vicepræsidentkandidat.

Deres parløb skulle markere et foreløbigt zenit for det miskrediterede embede. Aldrig tidligere i amerikansk historie har en vicepræsident 
haft så afgørende indflydelse på den førte politik. I starten (måske endda stadigvæk) misforstod medierne fuldstændig denne struktur, fordi der opstod et behov for at portrættere Bush som ubegavet.

Bush-lejren var selv medskyldig i denne proces, hvor man konsekvent satte folkelighed over enhver form for tilløb til at præsentere Bush som elitær. Valgkampe mod Al Gore og John Kerry, der begge havde et stort behov for at demonstrere deres omfattende kendskab til fremmedordbogen, havde skabt et behov for at placere Bush som det modsatte.

Bush ønskede at fremstå så folkelig, at man var på kanten af at kalde det for en succes, hvis han under debatter ikke savlede eller erklærede krig mod Frankrig. Derfor begyndte medierne at lede efter George W. Bushs hjerne: manden, der trak i trådene og styrede Bush. Kampagnelederen og den politiske rådgiver Karl Rove blev foreslået, men hurtigt overtog Richard Cheney denne rolle. Kort inde i Bushs præsidentperiode blev Cheney på forsiden af The Economist udpeget som USA's statsminister.

Dette dækkede alt sammen over en grov fejlvurdering af Bushs revolution af vicepræsidentembedet.

\section{Beslutningsdygtig}

I foråret 2005 blev Bush bedt om at beskrive det embede, han bestred. Han svarede, at jobbet $i$ al væsentlig- hed bestod $i$ at træffe beslutninger hele tiden. Det var det, vælgerne skulle spørge efter, når de vurderede præsidentkandidater: Hvordan og på hvilken baggrund traf de deres beslutninger. Senere skulle Bush beskrive sig selv med sit efterhånden typiske særegne greb om det engelske sprog som the decider.

Hemmeligheden bag Bushs pointe er, at præsidenten ikke træffer sine valg alene. En præsident er fuldstændig prisgivet den informationsstrøm, der kommer over hans bord. Problemet for en præsident er ikke mangel på information om givne problemstillinger, men at der er al for megen information, der strømmer mod det Ovale Værelse.

Og verden og amerikanerne forventer, at verdens mægtigste mand får information og rummer information om alt. En præsident er med andre ord aldrig bedre end den information, han eller hun måtte få.

Den fejlslagne invasion i Svinebugten i 1961 viser, hvor afgørende det er, hvorledes man organiserer Det Hvide Hus. En lille gruppe rådgivere og fortalere for den mislykkede invasion via stedfortræder, gav aldrig John F. Kennedy de oplysninger, han havde brug for og stillede aldrig spørgsmålstegn ved de underliggende præmisser for invasionens mulighed for succes.

Ingen præsident er bedre end de råd, han får, og Kennedy fik dårlige råd i 1961 med et katastrofalt resultat til følge. John F. Kennedy lærte 
af denne fejl og fik Det Hvide Hus omorganiseret med det resultat, at da Cubakrisen bevægede verden tættere og tættere på en verdenskrig, var præsidenten omgivet af en gruppe indbyrdes uenige, men begavede rådgivere, der kunne råde præsidenten præcist og uden at spilde tid på de forskellige synspunkter for givne handlingsforløb.

Den måde, Kennedy fik Det Hvide Hus organiseret på, betød, at han hurtigt kunne træffe beslutninger baseret på argumenter for og imod en given handling. Han fik hverken for få eller - hvilket var vigtigere for mange informationer og kunne derfor gøre det, han var valgt til: effektivt at lede.

Det er meget vanskeligt at organisere Det Hvide Hus ordentligt. Hvordan skal man udpege de informationer (ud af en endeløs informationsstrøm), som skal videre til præsidenten? Hvem skal afgøre, hvad der gør en oplysning til et stykke information, præsidenten skal tage stilling til? Hvem skal skrive den om i kort og præcis form, så man ikke spilder præsidentens tid? Hvordan undgår man, at de data, der når frem til præsidenten, ikke bliver politiseret eller poleret på deres vej gennem systemet?

Harry McPherson, der var rådgiver for Lyndon B. Johnson, formulerede opgavens vanskelighed på følgende facon: "Den virkelige fare var, at rådgiverne ville vægte argumenterne forkert. Selve processen med at reducere dusinvis af rapporter og høringsreferater til et tresiders memo til præsidenten betød, at man måtte udelade visse argumenter og data og fremhæve andre. Vi forsøgte at give ham begge sider af sagen, men vores egne synspunkter farvede det, vi skrev... Faren for ensidighed og udelukkelser er altid til stede og er uundgåelig, så længe præsidenten skal træffe 20 afgørelser om dagen baseret på information, han kun kan få gennem et filter bestående af andre menneskers overbevisninger".

Udviklingen, siden Johnson var præsident, har betydet, at præsidenten nu træffer mange flere beslutninger om dagen og er endnu mere prisgivet kontrollen med informationsstrømmen i Det Hvide Hus.

\section{Bedre organisering}

Det er en udvikling, der går helt tilbage til præsident Franklin D. Roosevelt (FDR). Et af New Deal-politikkens bivirkninger var, at den føderale sektor i USA begyndte at vokse. FDR forstod, at depressionen var en gave. Den ville give ham mulighed for at udvide embedets beføjelser uden at ændre Forfatningen (hvilket ville have været umuligt).

FDR indså, at han kunne vriste lederskabet af USA fra Kongressen ved at kræve det - netop fordi folket under indtryk af depressionens hærgen ledte efter lederskab og fandt det naturligst i præsidenten. 
New Deal-politikken havde som formål at hjælpe USA gennem depressionen og styrke den føderale sektor og præsidentens magt. FDR fik nedsat en kommission, der havde til opgave at undersøge præsidentembedets vilkår - velvidende at resultatet ville være en opfordring til at styrke embedet (FDR havde selv udpeget kommissionens medlemmer).

Kommissionens rapport (The Brownlow Report) lå klar i 1937 og opfordrede til, at den udøvende magt fik forøget sin stab betragteligt. Der skulle kreeres en ny struktur kaldet The Executive Office of the President (EOP), hvorfra præsidenten kunne lede hele den føderale offentlige sektor og alle dens ministerier. Denne struktur er den dag i dag grundlaget for præsidentens magt og har 1.600 ansatte og et budget på mere end trehundrede mio. dollar. Deres opgaver er at forbedre præsidentens kontrol over den udøvende magt, der i 2001 havde mere end 2.500.000 ansatte.

USA's 34. præsident (og første texaner i samme rolle), Dwight D. Eisenhower, er kendt for citatet: "Organisering kan ikke gøre en inkompetent til et geni... desorganisation fører næsten altid til ineffektivitet og kan let ende med katastrofe".

Clinton-administrationen var fyldt med dygtige og begavede rådgivere. Men der var ingen stram organisering og ingen kontrol over, hvem der gik ud og ind af præsidentens kontor. Resultatet var, at Clinton-administrationen i begyndelsen var noget af det mest politisk inkompetente, man havde oplevet, siden Ulysses Grant-administrationen kørte reorganiseringen af det borgerkrigshærgede Syden fuldstændig i sænk i 1870'erne.

Bill Clintons overgang fra kandidat til præsident i 1992-93 regnes af mange historikere og politiske iagttagere som en af de mest dilettantiske nogensinde. Der var ingen styr på Det Hvide Hus. Processen for udnævnelser af ministre osv. sejlede. Clinton havde ingen fornemmelse for, hvor dyrebar hans tid var og deltog i politiske diskussionsmøder, hvor alle kunne vade ind og ud.

Som sin første mærkesag valgte Bill Clinton at slå et slag for homoseksuelles rettigheder i militæret (selvom dette havde meget lav prioritet hos homoseksuelle interessegrupper) og at presse et omdiskuteret budget gennem Kongressen.

Uanset hvad man måtte mene om de to sager, var de forkerte politiske slagsmål på det forkerte tidspunkt. Konsekvensen blev, at Clinton trods et massivt Demokratisk flertal i begge Kongressens kamre fik gjort sine egne partifæller utrygge, hvilket førte til, at Republikanerne mobiliserede sig.

Da Clinton senere lancerede den reform af det amerikanske sundhedsvæsen, han havde håbet skulle være sit politiske svendestykke, led han et sviende nederlag. 


\section{Nye opgaver}

George W. Bush og Richard Cheney var meget opmærksomme på Clinton-administrationens problemer og skabte en ny struktur, der var uhyre effektiv. Det mest interessante ved den nye struktur var den magt, vicepræsidenten nu fik. Når en præsident ikke er bedre end de råd, han eller hun får, betyder det alverden at have adgang til præsidenten. Richard Cheney havde uindskrænket adgang til præsidenten. På intet tidspunkt tidligere i historien har en vicepræsident spillet så stor en rolle for sin præsident som under George W. Bush.

Siden F. D. Roosevelt har den føderale sektor i USA oplevet en eksplosiv vækst. Præsidenten har fået mere at se til og har brug for at uddelegere denne magt. Det specielle amerikanske system betyder dog, at præsidenten ofte ikke kan regne med, at hans egne embedsmænd er ham loyale, men ofte har deponeret dele af deres loyalitet i Kongressen.

Der ligger derfor en del magt og flyder i Det Hvide Hus. Præsidenten har ikke overskud til at samle den op og mister kontrol over sit embede ved at uddelegere den til sine ministre.

Løsningen på dette problem var enkel for George W. Bush: vicepræsidentembedet måtte styrkes. I Richard Cheney havde Bush den perfekte vicepræsident. Cheney havde ingen personlige politiske ambitio- ner og ville derfor være lettere at styre og stole på. Cheney kendte deslige alt og alle i Washington og forstod magtkampene mellem de forskellige grene af centraladministrationen.

Da Cheney opdagede dette, blev vicepræsidentembedet pludseligt uhyre attraktivt.

Da retssagen mod Cheneys stabschef, Lewis Libby, udfoldede sig, fik man et indblik i vicepræsidentembedets nye beføjelser. Det viste sig, at Richard Cheney havde en direkte linje til præsidenten og ofte endda kunne omgå præsidentens stabschef, hvilket er ganske usædvanligt. Richard Cheney kunne således hele tiden følge med i, hvilke oplysninger der nåede præsidenten og kunne påvirke $\mathrm{dem}$, når han fandt det nødvendigt.

\section{Overdiplomaten}

Følger man Cheneys politiske indsatsområder, er det tydeligt, at han lagde hovedparten af sine kræfter i at påvirke USA's sikkerhedspolitik, hvilket til dels fik det resultat, at traditionelle aktører på dette område, såsom forsvarsministeren og den nationale sikkerhedsrådgiver, fik deres indflydelse reduceret. Den aktør, der fik sin indflydelse mest undermineret, var udenrigsminister Colin Powell.

I et interview med Karen deYoung, der spurgte Powell, om en anden sikkerhedsrådgiver [end Condo- 
leezza Rice] med en stærkere personlighed ville have påvirket USA's sikkerhedspolitik, svarede han, at det fandt han ikke sandsynligt. På det opfølgende: "Hvorfor?" trak Powell på skuldrene og svarede: "Cheney".

Cheney satte sig så tungt på sikkerhedspolitikken, at han af journalisten Eric Scmitt blev kaldt for: krigsminister, überdiplomat, politisk rådgiver og consigliere (håndlanger/rådgiver ofte i mafiasammenhæng).

Cheney, der havde vettet sig selv til vicepræsidentposten, indførte en vetting-procedure for alle, der deltog i rekonstruktionen af Irak. Hvilket betød, at man havde en gruppe, der var meget loyale i spidsen for denne proces, men som ofte var så ideologisk enige, at de ikke havde den kakofoni af stemmer, som er meget nødvendig, hvis beslutninger skal træffes på det bedst mulige grundlag.
Dette nye vicepræsidentembede er den egentlige revolution i Det Hvide Hus, og vil sandsynligvis blive kopieret af Barack Obama, men i mindre grad skulle John McCain blive valgt.

Om et stærkere vicepræsidentembede er godt for USA, er en diskussion, der ofte bliver afsporet af politiske argumenter for eller imod Richard Cheneys politiske dagsorden. Uanset synspunkterne herfor, skal man i fremtiden være sig meget bevidst ikke bare, hvilken præsident man får, men også hvilken vicepræsident denne vælger at tage med sig.

Mads Fuglede er cand. mag. i historie og filosofi. Udgav for nyligt bogen "USA Den Universelle Nation” (Gyldendal 2008). 